\title{
Evaluation of Somatic Development in Adult Patients with Previously Undiagnosed and/or Untreated Phenylketonuria
}

\author{
Artur Mazur $^{\mathrm{a}}$ Sabina Jarochowicz ${ }^{\mathrm{a}}$ Jolanta Sykut-Cegielska ${ }^{\mathrm{b}}$ \\ Wanda Gradowska $^{b} \quad$ Andrzej Kwolek $^{a}$ Mariusz Ołtarzewski ${ }^{c}$ \\ ${ }^{a}$ Department of Physiotherapy, Faculty of Medicine, University of Rzeszów, Rzeszów, ${ }^{b}$ Departments of Metabolic \\ Diseases, Endocrinology and Diabetology, Children's Memorial Health Institute Warsaw, and 'National Research \\ Institute of Mother and Child, Warsaw, Poland
}

\section{Key Words}

Phenylketonuria, adult • Phenylketonuria, untreated •

Somatic development

\begin{abstract}
Objective: To evaluate physical growth, development and nutritional status in adults with previously undiagnosed/ untreated phenylketonuria (PKU). Methods: Four hundred adults (201 females and 199 males) with severe intellectual disability who were born prior to compulsory neonatal screening (before 1976) and who resided in social welfare homes in southeastern Poland were screened for PKU. The screening was performed by blood test using a tandem mass spectrometry method (MS/MS) and was confirmed by analysis of organic acids in urine. Eleven were identified as previously undiagnosed and/or untreated PKU cases. They underwent an assessment of their somatic development/status. Results: Among the 11 PKU patients (4 females and 7 males) the following characteristics were observed: poor physical growth after somatic development ( $n=8,2$ females aged 23 and 56 years and 6 males aged $28-59$ years); decreased head circumference - microcephaly $(n=5,1$ female aged 56 years and 4 males aged 28-59 years); poor body height ( $n=2$, 1 female aged 23 years and 1 male aged 59 years); poor tho-
\end{abstract}

racic circumference $(n=9,3$ females aged $23-56$ years and 6 males aged 28-59 years). Overall, body weight imbalance was noted in 9 (81.8\%) patients and irregularity of body proportions in 6 (54.5\%) patients. Conclusion: Our data showed the importance of nutritional surveillance and impact of metabolic imbalance on physical growth and body stature in untreated PKU patients. We therefore recommend an adequate and individually planned introduction of dietary intervention among that group of patients in order to ameliorate its nutritional status, general fitness and health.

Copyright $\odot 2009$ S. Karger AG, Basel

\section{Introduction}

After over 30 years of compulsory neonatal screening programmes in Poland, in which 8,267,190 children throughout the country were examined, the incidence for phenylketonuria (PKU) was estimated at 1:7,000 newborns $[1,2]$. Through effective screening programmes untreated PKU has been almost eliminated in the populations of the USA, Canada, the UK, France, Germany and many other countries worldwide [3]. However, there is evidence of cases of severe intellectual and physical disability resulting from undiagnosed and/or untreated

\section{KARGER}

Fax +4161306 1234

E-Mail karger@karger.ch

www.karger.com (c) 2009 S. Karger AG, Basel

$1011-7571 / 10 / 0191-0046 \$ 26.00 / 0$

Accessible online at:

www.karger.com/mpp
Artur Mazur, MD, $\mathrm{PhD}$

Institute of Physiotherapy, University of Rzeszów

ul. Warszawska 26a

PL-35-205 Rzeszów (Poland)

Tel. +48 178664 244, Fax +48 178664 145, E-Mail drmazur@poczta.onet.pl 
PKU [4-9]. While a large group of patients were born with various dysfunctions typical of untreated PKU prior to obligatory screening [10-12], some significant symptoms develop late in life [13-15]. Because of central nervous system damage, untreated PKU manifests with profound intellectual disability, severe behavioural disturbances, a variety of neurological deficits and other medical problems [13-15]. Although development of physical growth is generally normal, there are recognized characteristic physical features and abnormalities noticeable in the external appearance. Therefore, the aim of the study was to investigate whether or not chronically undiagnosed and untreated PKU could result in physical growth retardation and other aberrant physical features.

\section{Subjects and Methods}

The study was carried out during the period of December 2006 to April 2007 in all 12 social welfare homes for intellectually disabled people in southeast Poland. Residents who were born prior to the obligatory neonatal screening programme for PKU who had been diagnosed with intellectual disability (mental retardation) were enrolled in the study. Consequently, the screening test was performed on 400 residents (201 women, 199 men) born between 1917 and 1979. The mean age was 51 years (range 27-98). Two additional patients were included. One was born after the date of introduction of routine neonatal screening and was included because of suspicion of being a 'missed case'. The patient exhibited typical symptoms for classical PKU, both physical (fair colour of hair, skin, retina of the eye, enamel hypoplasia) and intellectual disability coexisting with challenging behaviour (agitation, aggression, self-injury, irritability). The other was an untreated PKU woman previously diagnosed with PKU in 1984 and who had no known family history. The screening for PKU was performed by standardized blood draw using tandem mass spectrometry method (MS/MS) and was confirmed by analysis of organic acids in urine.

Eleven patients ( 4 females, 7 males) were identified as being aged 23-59 years with previously untreated PKU. All were of white Polish ethnic background. The procedures followed were approved by the ethics committee, consent was obtained from legal caregivers because the majority had severe or profound intellectual disability. The following anthropometrical measurements were obtained: body height, body mass, chest circumference and head circumference. Body mass index (BMI) and Pignet-Verwaeck index (PVI) for body proportion assessment were calculated.

Qualified clinical nurses and physiotherapists carried out the measurements based on the technique recommended by Malinowski and Bożiłow [16]. The recorded data were compared with reference standards [16]. Body heights were measured in an upright basic standing position. Head circumferences were taken using the standard tailor tape and were carried out horizontally through skull glabella [points over the superior margin of eyebrow line and posterior cranium surface (major occipital convex-

Somatic Development in Previously

Undiagnosed and/or Untreated PKU ity)]. Chest circumference (armpit circumference) was recorded by carrying the tailor tape horizontally over the highest border of the axilla and without passing the natural contour of transition arm into trunk. These measurements were performed at rest and during normal quiet expiration [16]. BMI was estimated using the standard formula, BMI = body mass $(\mathrm{kg}) /$ body height $\left(\mathrm{m}^{2}\right)$.

For the purpose of determination of the body proportionality and figure (silhouette) types we estimated the PVI according to the formula: [body mass $(\mathrm{kg})+$ chest circumference at rest $(\mathrm{cm})] /$ body height $(\mathrm{cm}) \cdot 100$. The calculated data were analyzed according to the Saller classification for adults [16].

\section{Results}

The results of recorded measurements together with age, sex and blood phenylalanine levels of the PKU patients are presented in table 1 . In the present study 11 untreated PKU individuals were identified among a group of 401 subjects, which indicates that the incidence of undiagnosed and untreated PKU among the intellectually disabled Polish population (especially those born before 1976) may be 1 in 40.

The mean body height for studied males was $161.6 \mathrm{~cm}$ (range 150-170) and for females it was $153.5 \mathrm{~cm}$ (range 150-155). The mean Polish adult height for males is 174.1 $\pm 11.9 \mathrm{~cm}$ and for females it is $160 \pm 9.9 \mathrm{~cm}$. The mean body weight for males was $57.6 \mathrm{~kg}$ (range 43.5-85) and for females it was $52.1 \mathrm{~kg}$ (range 33-67). For normal population males it is $76 \pm 18.5 \mathrm{~kg}$ and for females it is $62 \pm$ $17.3 \mathrm{~kg}$. However, the body weight of 1 woman $(67 \mathrm{~kg})$ and 1 man $(85 \mathrm{~kg})$ was higher than the means of their gender.

The mean head circumference for males was $52.8 \mathrm{~cm}$ (range 50-56) and for females it was $52.5 \mathrm{~cm}$ (range 5156), compared to the Polish average of $57.1 \pm 2.6 \mathrm{~cm}$ for males and $54.9 \pm 2.6$ for females. Two females showed existence of microcephaly. Among 9 of the 11 PKU subjects ( 3 females and 6 males) the chest circumference was within the range for normal population.

The calculated BMI and body proportion index (PVI) are given in table 2 . The nourishment status according to BMI classification is shown in figure 1. The mean BMI was $22.2 \mathrm{~kg} / \mathrm{m}^{2}$ (range $13.91-34.92 \mathrm{~kg} / \mathrm{m}^{2}$ ). One female was classified as severely thin (BMI $13.91 \mathrm{~kg} / \mathrm{m}^{2}$ ), while 1 male was classified as mildly thin (BMI $17.2 \mathrm{~kg} / \mathrm{m}^{2}$ ). The BMI of 7 subjects ( 2 females and 5 males) were within normal range $\left(18.66-24.66 \mathrm{~kg} / \mathrm{m}^{2}\right)$. One female was preobese (BMI $28.25 \mathrm{~kg} / \mathrm{m}^{2}$ ) and 1 male was obese class I (BMI $\left.34.92 \mathrm{~kg} / \mathrm{m}^{2}\right)$. Overall abnormal BMI occurred in 4 $(36 \%)$ of the untreated PKU patients. 
Table 1. Physical development parameters, phenyloalanine blood levels, and age and sex data recorded among the studied group of patients

\begin{tabular}{|c|c|c|c|c|c|c|c|}
\hline Patient & $\begin{array}{l}\text { Age at } \\
\text { diagnosis } \\
\text { years }\end{array}$ & Sex & $\begin{array}{l}\text { Phenyl- } \\
\text { alanine } \\
\text { mg/dl }\end{array}$ & $\begin{array}{l}\text { Body } \\
\text { height } \\
\mathrm{cm}\end{array}$ & $\begin{array}{l}\text { Body } \\
\text { mass } \\
\mathrm{kg}\end{array}$ & $\begin{array}{l}\text { Head } \\
\text { circumference } \\
\mathrm{cm}\end{array}$ & $\begin{array}{l}\text { Chest } \\
\text { circumference } \\
\mathrm{cm}\end{array}$ \\
\hline 1 & 59 & $\mathrm{~m}$ & 29.80 & 157 & 46 & 51 & 69 \\
\hline 2 & 52 & $\mathrm{~m}$ & 28.66 & 164 & 63 & 56 & 94 \\
\hline 3 & 46 & $\mathrm{~m}$ & 25.04 & 159 & 43.5 & 52 & 85 \\
\hline 4 & 23 & $\mathrm{f}$ & 24.50 & 154 & 33 & 52 & 65 \\
\hline 5 & 45 & $\mathrm{f}$ & 24.07 & 155 & 53 & 53 & 83 \\
\hline 6 & 50 & $\mathrm{f}$ & 22.38 & 154 & 67 & 56 & 87 \\
\hline 7 & 56 & $\mathrm{f}$ & 21.85 & 150 & 55.5 & 51 & 80 \\
\hline 8 & 59 & $\mathrm{~m}$ & 21.63 & 156 & 85 & 54 & 108 \\
\hline 9 & 28 & $\mathrm{~m}$ & 18.46 & 161 & 52.5 & 50 & 92 \\
\hline 10 & 55 & $\mathrm{~m}$ & 10.08 & 170 & 57 & 54.5 & 85 \\
\hline 11 & 49 & $\mathrm{~m}$ & 9.52 & 164 & 56 & 53 & 83 \\
\hline \multicolumn{4}{|c|}{ Group mean $($ mean $\pm S D)$} & $158.5 \pm 5.77$ & $55.5 \pm 13.48$ & $53.0 \pm 2.00$ & $84.6 \pm 11.62$ \\
\hline \multicolumn{4}{|c|}{ Female mean $($ mean $\pm S D)$} & $153.3 \pm 2.22$ & $52.1 \pm 14.13$ & $52.5 \pm 2.16$ & $78.8 \pm 9.60$ \\
\hline \multicolumn{4}{|c|}{ Male mean (mean $\pm \mathrm{SD})$} & $161.6 \pm 4.86$ & $57.6 \pm 13.95$ & $52.8 \pm 2.09$ & $88.0 \pm 11.94$ \\
\hline
\end{tabular}

For Polish adults, average height for males is $174.1 \pm 11.9 \mathrm{~cm}$ and for females it is $160 \pm 9.9 \mathrm{~cm}$; average weight for males is $76 \pm 18.5 \mathrm{~kg}$ and for females it is $62 \pm 17.3 \mathrm{~kg}$; average head circumference for males is 57.1 $\pm 2.6 \mathrm{~cm}$ and for females it is $54.9 \pm 2.6 \mathrm{~cm}$; average chest circumference for males is $93.5 \pm 11.6 \mathrm{~cm}$ and for females it is $80.8 \pm 13.0 \mathrm{~cm}$.

Table 2. BMI and PVI recorded among the patients who did not have PKU

\begin{tabular}{clll}
\hline Patients & $\begin{array}{l}\text { Phenylalanine } \\
\text { levels } \\
\mathrm{mg} / \mathrm{dl}\end{array}$ & $\begin{array}{l}\text { Body mass } \\
\text { index } \\
\mathrm{kg} / \mathrm{m}^{2}\end{array}$ & $\begin{array}{l}\text { Pignet- } \\
\text { Verwaeck } \\
\text { index }\end{array}$ \\
\hline 1 & 29.80 & 18.66 & 73.2 \\
2 & 28.66 & 23.4 & 95.7 \\
3 & 25.04 & 17.2 & 80.8 \\
4 & 24.50 & 13.91 & 63.6 \\
5 & 24.07 & 22.06 & 87.7 \\
6 & 22.38 & 28.25 & 100 \\
7 & 21.85 & 24.66 & 90.3 \\
8 & 21.63 & 34.92 & 123.7 \\
9 & 18.46 & 20.25 & 89.6 \\
10 & 10.08 & 19.72 & 83.5 \\
11 & 9.52 & 21.72 & 84.8 \\
\hline Mean & $22.83 \pm 6.58$ & $22.2 \pm 5.68$ & $88.4 \pm 15.43$ \\
\hline
\end{tabular}

Normal ranges are: phenyloalanine levels $0.6-1.2 \mathrm{mg} / \mathrm{dl}$; BMI $18.5-24.9 \mathrm{~kg} / \mathrm{m}^{2}$; PVI 83.0-93.0 (according to Saller's classification).
The body proportion and silhouette types are illustrated in figure 2 . The mean of the body proportion index estimated according to the PVI was 88.4 (range 63.6123.7). Following the Saller classification 1 female had a very slender (asthenic) body build (PVI 63.6), 2 males demonstrated slender body build (PVI 73.2 and 80.8), 5 patients ( 2 females and 3 males) were characterized as medium body build, 2 patients with wide body build and 1 male with very wide body build.

\section{Discussion}

PKU represents a classical example in medical history of a genetically determined metabolic disease in which secondary prophylactic intervention effectively prevents the disease consequences through early recognition and introduction of treatment at a symptomatic stage. Over the last 40 years, the efficacy of neonatal screening programmes for PKU in Poland, and worldwide, has been proven through the investigation of millions of newborns. In this study the 11 cases of previously untreated PKU adults were similar to 17 cases out of 975 residents reported in the region of Western Pomerania $[9,10]$. 
Fig. 1. The nourishment status of PKU patients according to BMI classification.
Fig. 2. Body proportions and silhouette types of PKU patients according to PignetVerweack index.
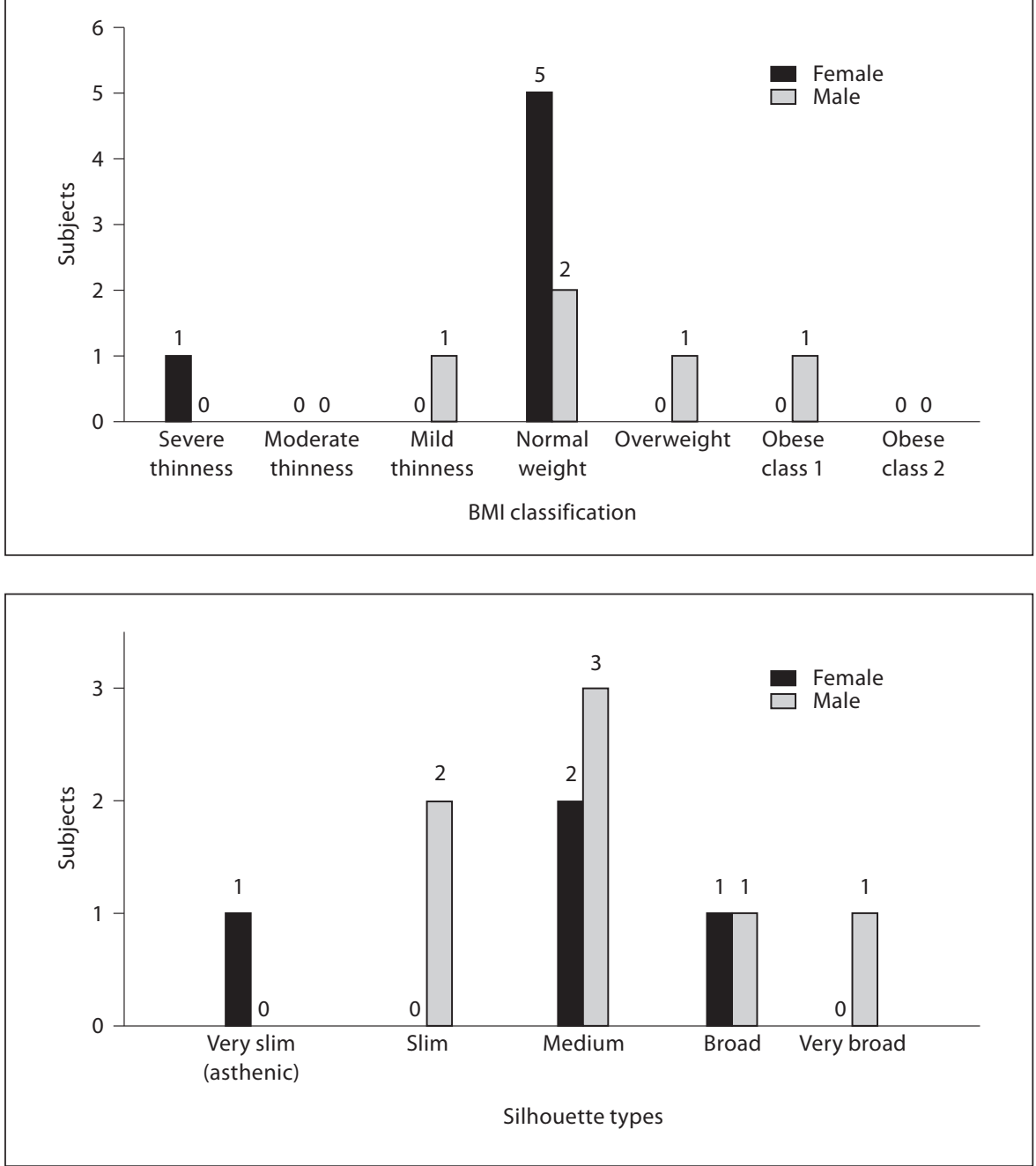

Mean life span of 49.9 years in our study was slightly higher than the 40.4 years found in the other studies, but the oldest untreated patient was approximately the same age (59 years in our study vs. 57.8 in the other studies) [10-11].

The last decades of research and clinical experience have shown that in untreated PKU patients somatic development generally remains normal, but that some other abnormal characteristics appear to be inevitable. The reports published in worldwide literature [17-19] show a diversity of opinion in relation to physical impairment that could be related to the phenotype variety of this disease. Apart from microcephaly (noted in $68-94 \%$ of patients) in originally untreated PKU a common phenomenon was physical growth retardation (decreased body height and underweight, ranging from mild to extreme emaciation) [17]. In the early 70's in Poland, Goncerzewicz and Socha [18] found poor physical growth among children with chronically untreated PKU. Holm and Knox [19] found that among 323 patients with clinically diagnosed but untreated PKU, posture was assessed as normal, but in 31 institutionalized cases the mean body height and head circumference decreased. Giżewska et al. [11] reported similar findings in 17 adults with previously untreated or only temporarily treated PKU. The findings of our study confirmed these previous reports. Equally, the number of subjects who were overweight and classified as pre-obese and obese class 1 in our study is consistent with excessive body mass recorded as overweight in the course of previously and chronically untreated PKU $[4,8,20]$. 
Taking these into account, the presence of poor height, body weight, chest circumference and also the existence of microcephaly found in the majority of our patients, we suggest that growth retardation and emaciation could be regarded as long-lasting effects of chronically untreated PKU on overall physical growth development.

Several authors $[4,8,11]$ have demonstrated the evidence of positive changes in BMI among chronically and previously untreated PKU adults after introduction of a low- phenyloalanine diet. Giżewska et al. [11] showed normalization of BMI by lowering phenyloalanine blood levels in 3 of 4 patients with abnormal BMI. Yannicelli and Ryan [8] and Fitzgerald et al. [4] demonstrated improvement in body mass through dietary intervention and lowering phenyloanine blood levels, respectively.

\section{Conclusions}

Our data show the importance of nutritional surveillance and impact of metabolic imbalance on physical growth status and body stature in untreated PKU patients. We therefore recommend an adequate and individually planned introduction of dietary intervention among that group of patients in order to ameliorate their nutritional status, general fitness and health.

\section{References}

1 Tylek-Lemańska D, Starzyk J: Fenyloketonuria i hipotyreoza u dzieci. Polska Medycyna Rodzinna 2003;5:307-316.

- 2 Bożkowa K, Cabalska B, Radomyska B, Ołtarzewski M, Lenartowska: Ocena przydatności badań przesiewowych u noworodków w świetle 35 lat doświadczeń własnych. Medycyna Wieku Rozwojowego 1999;3:529559.

3 Phenylketonuria (PKU): Screening and management. NIH Consens Statement 2000; 17:1-33.

-4 Fitzgerald B, Morgan J, Keene N, Rollinson R, Hodgson A, Dalrymple-Smith J: An investigation into diet treatment for adults with previously untreated phenylketonuria and severe intellectual disability. J Intellect Disabil Res 2000;44:53-59.

5 Koch R, Burton B, Hoganson G, Peterson R, Rhead W, Rouse B, Scott R, Wolff J, Stern AM, Guttler F, Nelson M, de la Cruz F, Coldwell J, Erbe R, Geraghty MT, Shear C, Thomas J, Azen C: Phenylketonuria in adulthood: a colaborative study. J Inherit Metab Dis 2002;25:333-346.

-6 Brown MCJ, Guest JF: Economic impact of feeding a phenyloalanine-restricted diet to adults with previously untreated phenylketonuria. J Intell Disabil Res 1999;43:30-37.
7 Gassió R, Campistol J, Vilaseca MA, Lambruschini N, Cambra FJ, Fusté E: Do adult patients with phenylketonuria improve their quality of life after introduction/resumption of a phenylalanine-restricted diet? Acta Paediatr 2003;92:1474-1478.

-8 Yannicelli S, Ryan A: Improvements in behavior and physical manifestations in previously untreated adults with phenylketonuria using a phenyloalanine-restricted diet: national survey. J Inherit Metab Dis 1995;18: 131-134.

-9 Kalkanoğlu HS, Ahring KK, Sertkaya D, Møller LB, Romstad A, Mikkelsen I, Guldberg P, Lou HC, Güttler F: Behavioural effects of phenylalanine-free amino acid tablet supplementation in intellectually disabled adults with untreated phenylketonuria. Acta Paediatr 2005;94:1218-1222.

10 Giżewska M: Fenyloketonuria jako przyczyna niepełnosprawności intelektualnej u osób dorosłych przed erą noworodkowych badań przesiewowych - mechanizm neurotoksyczności fenyloalaniny. Fam Med Prim Care Rev 2006;8:386-391.

11 Giżewska M, Ołtarzewski M, Sendecka E: Pacjenci $\mathrm{z}$ fenyloketonurią urodzeni przed wprowadzeniem badań przesiewowych: różne oblicza tej samej choroby. Postępy Pediatrii 2003;2:24-32.

12 Robertson L: Adults with previously untreated PKU: trial update. Nat Soc Phenylketonuria Conf, Hinckley, 2006. www.nspku.org/ Documents/Conf_abstracts/Conference_ Abstracts_2006.pdf.
13 Kasim S, Moo LR, Zschocke J, Jinnah HA: Phenylketonuria presenting in adulthood as progressive spastic paraparesis with dementia. J Neurol Neurosurg Psychiatry 2001;71: 795-797.

14 Weglage J, Oberwittler C, Marquardt T, Schellscheidt J, von Teeffelen-Heithoff A, Koch G, Gerding H: Neurological deterioration in adult phenylketonuria. J Inherit Metab Dis 2000;23:83-84.

- 15 Pietz J, Dunckelmann R, Rupp A, Rating D, Meinck HM, Schmidt H, Bremer HJ: Neurological outcome in adult patients with earlytreated phenylketonuria. Eur J Pediatr 1998; 157:824-830.

16 Malinowski A, Bożiłow W: Podstawy antropometrii: metody, techniki, normy. Warszawa, PWN, 1997.

17 White JE, Kronmal RA, Acosta PB: Excess weight among children with phenylketonuria. J Am Coll Nutr 1982;1:293-303.

18 Goncerzewicz M, Socha J: Ocena stanu odżywienia dzieci z nieleczona fenyloketonurią. Pediatr Pol 1973;48:567-574.

19 Holm VA, Knox WE: Physical growth in phenylketonuria: a retrospective study. $\mathrm{Pe}$ diatrics 1979;63:694-699.

20 Dhondt JL, Largillière C, Moreno L, Farriaux JP: Physical growth in patients with phenylketonuria. J Inherit Metab Dis 1995;18: 135-137. 